\title{
Analysis of Urban Land Use and Land Cover Change for Sustainable Development: A Case of Lafia, Nasarawa State, Nigeria
}

\author{
Banki Thomas Chunwate', Sani Yahaya', Ishaya Kunden Samaila', Shittu Whanda Ja'afaru² \\ ${ }^{1}$ Department of Geography, Nasarawa State University, Keffi, Nigeria \\ ${ }^{2}$ Department of Geography, Gombe State University, Gombe, Nigeria \\ Email: banki.chunwate@nsuk.edu.ng, optimistbanki4u@gmail.com, yasani247@yahoo.com, ikunden@yahoo.com, \\ shittuwhanda@yahoo.com
}

How to cite this paper: Chunwate, B.T., Yahaya, S., Samaila, I.K. and Ja'afaru, S.W. (2019) Analysis of Urban Land Use and Land Cover Change for Sustainable Development: A Case of Lafia, Nasarawa State, Nigeria. Journal of Geographic Information System, 11, 347-358.

https://doi.org/10.4236/jgis.2019.113021

Received: May 23, 2019

Accepted: June 15, 2019

Published: June 18, 2019

Copyright @ 2019 by author(s) and Scientific Research Publishing Inc. This work is licensed under the Creative Commons Attribution International License (CC BY 4.0).

http://creativecommons.org/licenses/by/4.0/

\begin{abstract}
Inventories on land use/cover changes are assessed at increasing importance in various sectors, like agriculture, settlement, environmental studies and urban planning. This research was carried out to analyse the changes in urban land use/cover of Lafia for the years 1986, 2000 and 2014. Remotely sensed data from Landsat TM and Nigeria sat 8 were classified using GIS technique, to which six categories of land use/cover were identified such as: bare surfaces, built up areas, cultivated lands, rocky outcrops, vegetation cover and wetlands. Population data of the study area for 1986, 2000 and 2014 were also used to compare the relationship between population growth and landuse/cover changes in the study area using descriptive statistics. The result revealed an increase in built up areas from $1.56 \%$ to $15 \%$ between 1986 and 2014 while vegetation cover showed decrease: from $25 \%$ in 1986 to $12 \%$ in 2014. Cultivated lands increased from $56 \%$ in 1986 to $67 \%$ in 2014 . Others classes such as: bare surfaces decreased, as wetlands and rock outcrops seem to be fluctuated. Therefore results from the analyses indicate a general change in landcover for the periods under this study. This study recommends that: there is a need to monitor the changes that occurred on land use so as to provide proper planning and effective management of the land resources in a sustainable manner.
\end{abstract}

\section{Keywords}

Land Use/Cover, Changes, Sustainability, Development, GIS Application

\section{Introduction}

Humans through activities such as clearing forests for crop cultivation, road 
construction and grazing have altered much of the world's natural vegetation (Giri, 2001) [1]. The result is that the vegetation cover we see today has little resemblance to the original cover in many years ago in places; hence these places have little natural vegetation present.

Effective management of forest and land resources requires an understanding of the patterns and processes of land use and land cover change and the consequences affecting a particular management decision. Monitoring and evaluation provide basic data from which effectiveness can be determined and with which a plan can be modified to reinforce the components that are successful and to correct those processes that were not successful.

Man has altered his natural environment to suit himself, in a bid to make it more comfortable for survival. This change in the environment has impacted the structure and function of the ecosystem. More than half of the earth's inhabitants reside in urban areas and this number is increasing globally (Martin, 2007) [2]. Most major cities (metropolitan areas) in developing countries face growing problems of urban sprawl, loss of natural vegetation and decreased wildlife results among others.

Land use and land cover change (LULCC), also known as land change, is a general term for the human modification of earth's terrestrial surface (Ellis, 2011) [3]. Scientist and the public now understand that contemporary change in many realms of the biosphere is largely the product of human activities (Meyer and Tuner, 1994). Some of these activities are due to specific management practices and the rest are due to social, political and economic forces that control land use (Medley et al., 1995) [4].

Meyer and Turner (1992) [5] asserted that changes in land use and land cover affect global systems (e.g. atmosphere, climate, forest and sea level) and have a significant effect in localized places where they occur. Because of their great influences in global warming, loss of biodiversity, and impact in human life, the international Geosphere-Biosphere Program (IGBP) and the International Human Dimension Program (IHDP) initiated a joint international program of study (LUCC). A study of land use and land cover change is essentially the analysis of the relationship between people and land. It involves the questions on why; when, how and where does land use change occur? Land use change is always caused by multiple interacting factors. The mix of the driving forces of land use change however varies in time and space according to specific human-environmental conditions. Land use change requires an understanding of how people make land use decision and how various factors interact in specific contexts to influence decision on land use. Decision-making is influenced by factors at the local, regional or global scale (Verburg et al., 2012) [6].

Over the last decades, there has been a worldwide increase in awareness on the effect of land use/land cover dynamics and studies on land use land cover change analysis (Ademiluyi, 2013) [7]. There is however low level of research attention on land use land cover studies in most parts of North-Central Nigeria especially in Nasarawa State and the country in general. Also, most of the few 
studies carried out on land use land cover analysis and change detection rely on a one factor approach and depend on analogue rather than the modern digital image interpretation and analysis procedure which is known to produce better results ( $L i$, et al., 2013) [8]. It is against the background of the use of modern digital image interpretation and multi-factor approach that this research attempts to analyse land use land cover change in Lafia using remote sensing and geographical information system (GIS) techniques.

The study aim at analyse urban land use change of Lafia, Nasarawa State using remote sensing and GIS techniques for sustainable development. To achieve this, maps of LULC of the area for the period 1986, 2000 and 2014 were generated to examine possible changes in different LULC type, as well as assess the trend, rate and magnitude of changes witnessed from 1986 through 2014.

\section{Material and Methods}

The study area is located between latitude $8^{\circ} 20^{\prime} \mathrm{N}-8^{\circ} 38^{\prime} \mathrm{N}$ and between longitudes $6^{\circ} 34^{\prime} \mathrm{E}-7^{\circ} 30^{\prime} \mathrm{E}$. It share boundaries with Nasarawa Eggon and Wamba Local Government Area (L.G.A) in the North, Obi Local Government Area (L.G.A) in the South East, Doma Local Government Area (L.G.A) in the South-West, Kokona Local Government Area (L.G.A) in the West and Plateau state in the East respectively (Figure 1). The climate exhibited in the area under study shows no difference from that experienced over other parts of the Nasarawa State, which is characterized by a sub-humid climate with two distinct seasons; dry and rainy season (Akwa et al., 2005) [9]. The study area has population of 330,712 according to National Population Commission Lafia (2006) [10]. The area falls within the guinea savanna zone characterized by scattered trees and grasses. The geology comprised of the basement complex formation of North Central Nigeria with undulating low lands and network of hills developed on granites, magnetite rocks which are believed to be plutonic in nature but later exposed to the surface by geomorphic processes.

\subsection{Methods}

Three sets of satellite images of the Lafia Local Government Area for the years 1986, 2000 and 2014 with green, red and near infrared bands were used for this study. The 1986 (Enhanced Thematic Mapper (ETM)). 2000 image also from land Sat-5 and the 2014 is from Nigeria Sat 8 OLI (Table 1). These images were employed in classifying the land use/land cover of the Lafia Local Government Area.

ILLIWIS 3.3, ERDAS IMAGINE 9.2, ArcGIS 10.1, MS Excel, Microsoft Office were used to extract and classify the land use and land cover of the study area. Results were summarized in tables, figures and were discussed using descriptive statistics.

The land cover classes were defined based on the Anderson's level 1 classification system (Ernest E Hardy, John Roach, Richard E. Geological Survey Professional paper 1964, United States Printing Office, Washington 1976 and Anderson et al., 1976) [11]. After the images were geo-referenced and geometrically 


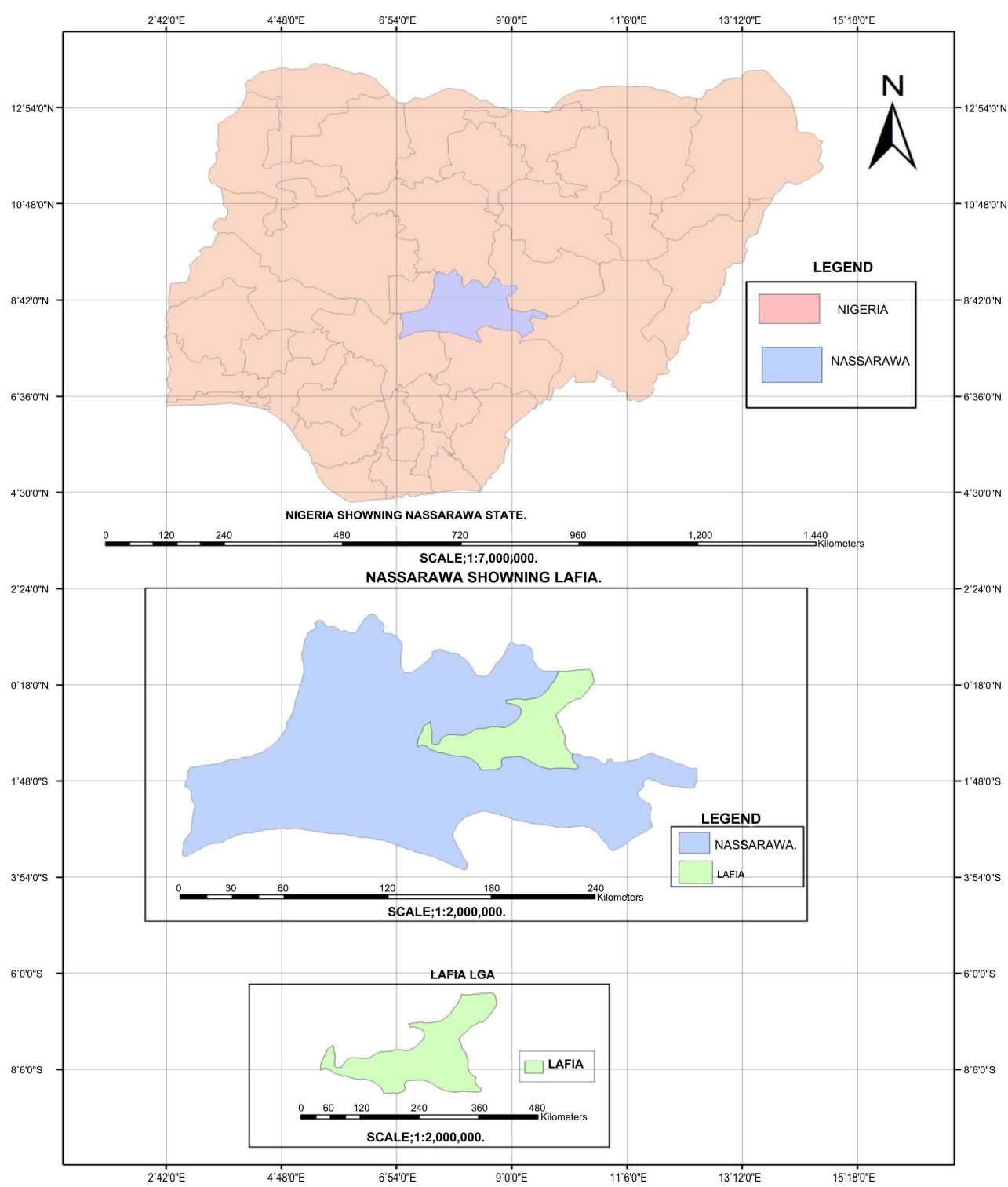

Figure 1. The study area. Source: NASRDA, 2015 and field exercise work, 2015.

Table 1. The images characteristics.

\begin{tabular}{cccc}
\hline No & Type of data/Sensor & Scale of resolution & Year/Month \\
\hline 1 & LANDSAT 5 ETM & $30 \mathrm{~m}$ & $1986 / \mathrm{Jan}$ \\
2 & LANDSAT 5 TM & $30 \mathrm{~m}$ & $2000 / \mathrm{Feb}$ \\
3 & Nigeria Sat 8 OLI & $15 \mathrm{~m}$ & $2014 / \mathrm{Jan}$ \\
\hline
\end{tabular}

Source: NASRDA, 2015 and field exercise work, 2015.

rectified. Image clipping was performed, using spatial analyst tool on a sub-scene from the full image on the basis of a frame covering the area of the study. These preprocessing tasks allowed the export of the satellite images to the ArcGIS and ERDAS for classification and extraction of land cover information. Supervised classification was performed on the same images, with random training samples 
using on-screen digitizing from on the standard menu of the software; Land cover types classification and identification were performed. The 1986, 2000 and 2014 images provided a means to determine LULC in the categories; built-up area, bare surfaces, cultivated lands, rocky outcrops, vegetation and wetlands.

The area coverage for each land use/land cover types was calculated for the years covered by this study. This was done to develop a table showing the area in square kilometers and the percentage change for the years 1986, 2000 and 2014.

Percentage change was calculated by dividing observed change by sum of changes multiplied by 100 .

$$
\text { percentage change }=\frac{\text { observed change } \times 100}{\text { Sum of change }}
$$

\subsection{Calculation of Magnitude and Percentage Rate of Change}

The calculation of the magnitude of change was derived by subtracting the observed change of each period (land use and land cover in $\mathrm{Km}^{2}$ ) of the recent years by the previous recent years.

The calculation of the trends, that is, the percentage rate of change of each of the landuse type, by subtracting the percentage of the more recent year land use/cover by the previous year land use and land cover.

\section{Results and Discussion}

The results of land use and land cover of the study area are presented in Table 2 \& Table 3 and Figure 2 \& Figure 3.

\section{Discussion on Results of Analysis of Land Use and Land Cover Changes}

The result of the analysis revealed that many changes had occurred in land use and land cover in the study area in 28 years (1986-2014). It shows that there are remarkable changes in some land uses and land covers. It also shows that percentage changes in some land use and land cover categories such as built-up

Table 2. Land use and cover change for the years 1986, 2000 and 2014.

\begin{tabular}{ccccccc}
\hline $\begin{array}{c}\text { Categories of } \\
\text { land/cover type }\end{array}$ & $\begin{array}{c}\mathbf{1 9 8 6} \\
\text { Area }\left(\mathrm{km}^{2}\right)\end{array}$ & $\begin{array}{c}\% \\
\text { Area }\end{array}$ & $\begin{array}{c}\mathbf{2 0 0 0} \\
\text { Area }\left(\mathrm{km}^{2}\right)\end{array}$ & $\begin{array}{c}\% \\
\text { Area }\end{array}$ & $\begin{array}{c}\mathbf{2 0 1 4} \\
\text { Area }\left(\mathrm{km}^{2}\right)\end{array}$ & $\begin{array}{c}\text { Area } \\
\text { Area }\end{array}$ \\
\hline Bare surfaces & 96.66 & 3.5 & 37.83 & 1.37 & 6.35 & 0.23 \\
Built-up areas & 43.08 & 1.56 & 132.56 & 4.8 & 414.25 & 15.0 \\
Cultivated lands & 1546.52 & 56.0 & 1767.45 & 64.0 & 1850.29 & 67.0 \\
Rock out crops & 175.09 & 6.34 & 30.12 & 1.09 & 79.26 & 2.87 \\
Vegetation cover & 690.41 & 25.0 & 502.89 & 18.21 & 331.39 & 12.0 \\
Wet lands & 209.88 & 7.6 & 290.80 & 10.53 & 80.09 & 2.9 \\
TOTAL & 2761.634 & 100 & 2761.634 & 100 & 2761.634 & 100 \\
\hline
\end{tabular}

Source: NASRDA, 2015 and field exercise work, 2015. 
Table 3. Trend, rate and magnitude of change for land use and land cover of the study area.

(a)

\begin{tabular}{ccc}
\hline LAND USE/COVER TYPE & $2000-1986$ & $2014-2000$ \\
\hline Built up area & AREA (sq. km) & AREA (sq. km) \\
Vegetation cover & +89.5 & +281.6 \\
Cultivated land & -187.5 & -171.5 \\
Wetlands & +220.9 & +82.8 \\
Rock_outcrops & +80.92 & -210.712 \\
Baresurface & -145 & +49 \\
\hline
\end{tabular}

+ indicates an increase; - Indicates a decrease

(b)

\begin{tabular}{ccc}
\hline LAND USE/COVER TYPES & $2000-1986$ & 2014-2000 \\
\hline Built up area & Percentage (\%) & Percentage (\%) \\
Vegetation cover & +3.24 & +10.2 \\
Cultivation land & -6.79 & -6.21 \\
Wet-lands & +8 & +3.0 \\
Rock_outcrops & +2.93 & -7.63 \\
Bare-surfaces & -5.25 & +1.78 \\
\hline
\end{tabular}

+ indicates a percentage increase; - Indicates a percentage decrease. Source: NASRDA, 2015 and field exercise work, 2015.

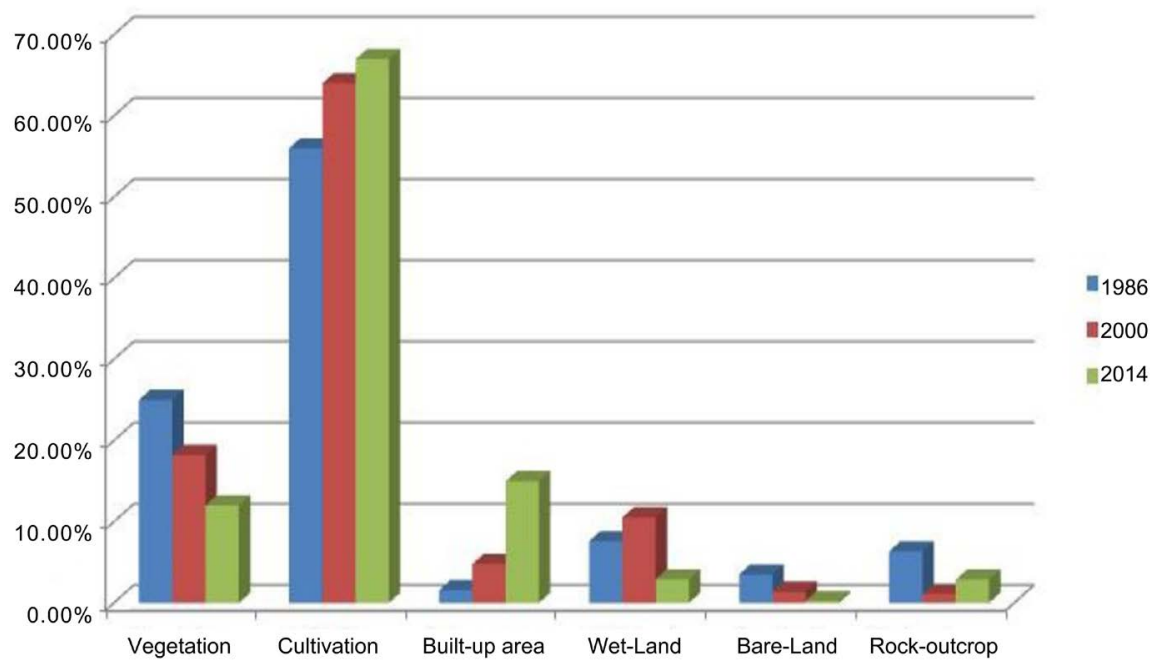

Figure 2. Comparative distribution of land use and land cover of the study area for the years 1986, 2000 and 2014. Source: NASRDA. Abuja and Field Exercise, 2015.

areas and cultivated lands have increased, whereas rock outcrops indicate a decrease in the early period and increase over the latter years. Others such as vegetation cover and bare surfaces, have experienced decline over the years (Table 2 


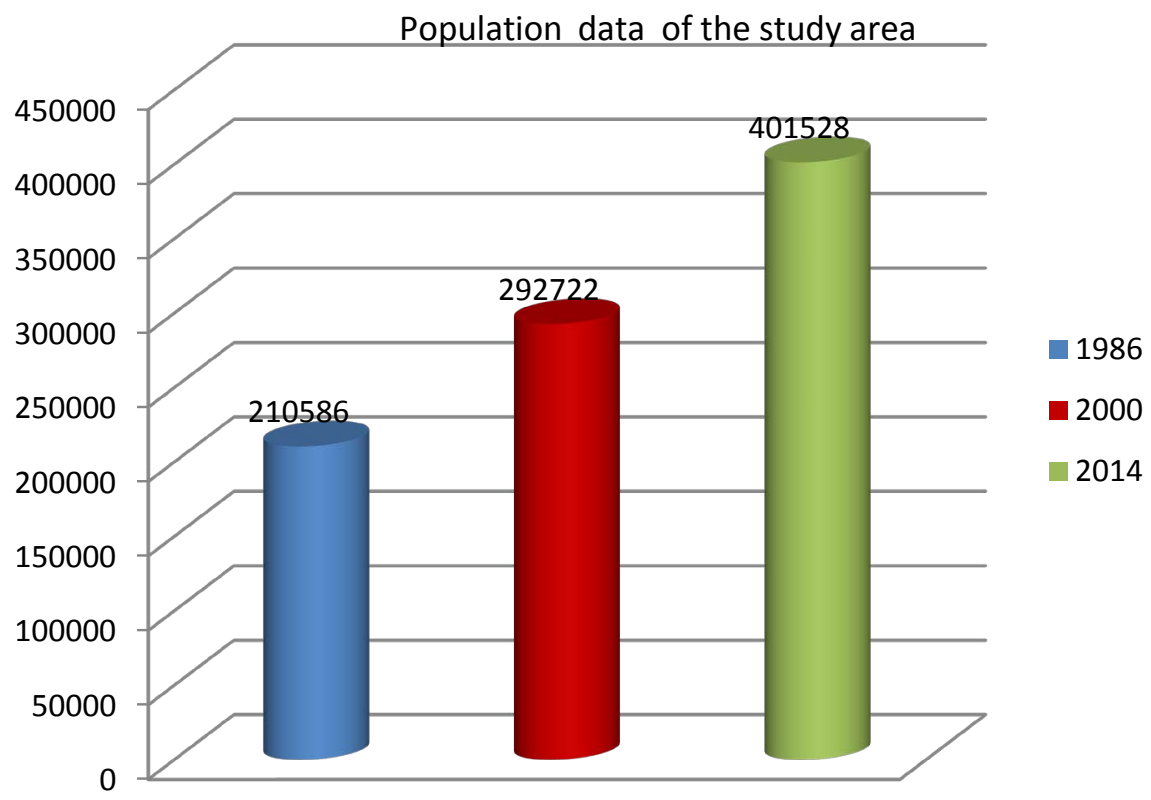

Figure 3. Population data of the study area. Source: National population commission, Lafia and Field Exercise, 2015.

and Figure 2) Cultivated lands accounted for $56 \%$ of the total land area in 1986, increased to $64 \%$ in 2000 and rose to $67 \%$, in 2014 . The cultivation land kept increasing such that it occupied $1546.52 \mathrm{~km}^{2}$ in $1986,1767.45 \mathrm{~km}^{2}$ in 2000 and slightly increasing to $1850.29 \mathrm{~km}^{2}$ of the total land area in 2014 (Table 2). This result implies that the major activity of the study area is farming, and increased farming activities may be due to an increase in population, which led to demand for agricultural products for both subsistent and commercial purposes. For example some of the communities in areas such as; Akurba, Shabu, Ombi 1 and 2, in the Northern District of the area and Tudun Kauri, the Southern District amongst others; mostly engage in farming activities. Banki (2009) [12] carried out similar research in Akwanga, in Nasarawa State; and noticed that population is a major factor that triggers the increase in the rate of cultivation of the area.

\section{1) Vegetation Cover}

Vegetation cover includes all the forested areas and grasslands. The result of the analysis shows that in 1986, vegetation accounted for about $25 \%$ of the total area, but decreased to $18.21 \%$ in 2000 and further decline to $12 \%$ in 2014 (Table 2 and Figure 2). However, the reason for this decline is a result of an increase in population which has resulted in encroachment into forest areas for domestic fuel, clearing of grassland for farming and building; thereby causing massive alteration of the natural vegetation covers. In line to this, Jatau (2012) [13] carried out a study on geospatial analysis of urban land use change in the Jos metropolis, and noticed that the vegetation cover decreased or changed in the area was caused by mass movement of people from the rural areas to find a better livelihood believed to be available in the urban areas. Also, (Chukwunonson 2012) [14] conducted a similar research in Bauchi on the impact of land use and land cover 
change in the Yankari Games Reserve park. He discovered that agricultural activities caused the rapid decrease in vegetation in the area.

\section{2) Wetlands}

From Table 2. Wetlands which include all surface water bodies, such as ponds, streams, rivers, marshes and lakes, between 1986 and 2000 increased from 209.88 $\mathrm{km}^{2}$ to $290.80 \mathrm{~km}^{2}$. This change may be as a result of change in weather conditions (NIMET, 2015) [15]. It can be inferred that most of waterlogged areas that accounted for surface water has appeared and minor streams have continued to retain water, the sizes of rivers and streams may have increased, this could have resulted in more wetlands, but the situation changed between 2000 and 2014 . The wetland decrease from $290.80 \mathrm{~km}^{2}$ to $80.09 \mathrm{~km}^{2}$, may be attributed to weather variation and also as a result of increase in population in the area. Most of this wetland area is being converted into cultivated lands. For example most of mashes; and waterlogged areas are used for cultivation of rice, sugarcane, vegetables and fruit like water mellon, in Kilima, Ombi I and II, Shabu, Akurba and others part of the study area.

\section{3) Rock outcrops}

These include all hilly and rocky areas, and consist of the different types of rocks found in the area. The result shows that rock outcrops witnessed a decrease and then an increase over the years under this study, from $175.09 \mathrm{~km}^{2}$ in 1986 to $1.09 \mathrm{~km}^{2}$ in 2000 , that is $6.34 \%$ against $1.9 \%$ of the total land area. The reasons for the decrease may be attributed to (quarrying) by the people living in the area for economic and industrial purposes. In fact, in some locations within the study area people build on top of the rocks. This also may contribute to the decrease. However, rock outcrops increased from $1.090 \%$ in 2000 to $2.87 \%$ in 2014. This may result from farming activities (practices) that exposed some of the rocks. Also decreasing and declining vegetal covers of the area within this period as a result of human activities may lead to exposure of more rocks in the study area.

\section{4) Bare surfaces}

Bare surfaces include: untarred roads (foot paths) and wasteland. According to Table 2, the result shows that bare surfaces accounted for 3.5\% in 1986, while in 2000 decreased to $1.37 \%$, and dropped down to $0.23 \%$ in 2014 . That is these surfaces declines in the area from $96.66 \mathrm{~km}^{2}$ to $1.45 \mathrm{~km}^{2}$. The reason for the change is that; bare lands have been developed into settlements and places where built-up areas have increased. For example, Ombi I, II, Shabu, BukanSidi where the College of Agriculture and Nasarawa State Polytechnic Lafia are located has increased outwardly. Many open areas have been converted to houses for accommodations due to the number of students in the institutions, and also for commercial purposes, coupled with the state Capital, Lafia continues to record many developments that led to conversion of bare surfaces for administrative and others infrastructural development.

\section{5) Build-up areas}

The built-up areas increased significantly over the years of this study, from 
$43.08 \mathrm{~km}^{2}$ in 1986 to $132.56 \mathrm{~km}^{2}$ in 2000 and rise to $414.25 \mathrm{~km}^{2}$ in 2014 , representing 1.56\%, 4.8\% and 15\% respectively (Table 2, Figure 2 and Figure $3)$. This change is attributed to increase in population, which brought about high demand for shelter, commercial activities and basic amenities. Arulbalaji and Gurugnanam (2014) [16], also carried out a study on Geospatial Science for 16 Years of Variation in Land Use/Land Cover Practice Assessment around Salem District, South India (1992-2008). They identified human population and anthropogenic activities as the main causes of increase in built-up-lands. The vegetation in Lafia is almost gone as a result of built-up areas. For example the Nasarawa State Polytechnic, College of Agriculture Lafia, Nasarawa State University, Keffi (Faculty of Agriculture Campus), National Open university Lafia Campus, Federal University, Lafia and School of Nursing Lafia Campuses which are located in the northern, southern and eastern part of the area (Lafia), the higher educational institutions located in the area have also increased the built up areas due to high demands for accommodation by the students, thus landowners have converts their plots of land for residential and commercial purposes leading to more bare surface and vegetation area into built-up area. For example, lands area located close to these various higher institutions are; Ombi 1 and 2, Bukan Sidi, Millionaires Quarters, Mararaba Lafia, Tudun Gwandara areas were converted to settlements.

Also human activities in the area have altered the environment in one way or another to suit human needs. Another reason is attributed to the crisis that encroached in the northern part of the country, where many people find their way to Lafia city to settle. Again due to crisis within the southern part of the state may also be a pull factor for people to acquiring lands to build in Lafia, the state capital. The untarred roads-have been widened and converted to major township roads, coupled with new construction has undoubtedly increased the extension of the built up areas into bare surfaces.

Table 3 shows the trend, rate and magnitude of change of land use and land cover of the study area for the three years 1986, 2000 and 2014. Some of the classes increase while others decrease within the years cover by this study. Built up area have a magnitude of change of $+89.5 \mathrm{~km}^{2}$, with a rate of change $+3.24 \%$ between 1986-2000 while Vegetation covers has $-187.5 \mathrm{~km}^{2}$ as magnitude of change with the rate of change of $-6.7 \%$ respectively. Cultivated lands are accounted for $+220.9 \mathrm{~km}^{2}$ for magnitude of change and rate of change of $+8 \%$ between 1986 and 2000. Wetlands have a magnitude of $+80.92 \mathrm{~km}^{2}$ with the rate of change of $+2.93 \%$ within $1986-2000$. Others such as rock outcrop and bare surface records $-145 \mathrm{~km}^{2},-58.82 \mathrm{~km}^{2}$ in magnitudes and $-5.25 \%,-2.13 \%$ as their rate of changes respectively.

Therefore; the trend of change between 2000 and 2014 is such that, the built up area has $+281.6 \mathrm{~km}^{2}$ in magnitude with $+10.2 \%$ rate of change. Vegetation covers accounted for $-171.5 \mathrm{~km}^{2}$ as magnitude and $-6.21 \%$ of the rate of change between 2000 and 2014. Cultivation land magnitude was $+82.8 \mathrm{~km}^{2}$ with the rate 
of change of $+3 \%$ respectively. Wetlands magnitude was $-210.71 \mathrm{~km}^{2}$, with the rate of change of $-7.63 \%$ between $2000-2014$. Rocks outcrops and bare surfaces magnitude were $+49 \mathrm{~km}^{2}$ and $-31.48 \mathrm{~km}^{2}$ with the rate of change of $+1.78 \%$ and $-1.14 \%$ within this period (2000 and 2014).

From the result of the trend rate and magnitude of change of land use and land cover of the study area, this implies that the built up areas is taken over the bare surface portion while cultivations is also taken portion for wetlands and vegetation covers and rock outcrop is losing to either built up lands or cultivation and gaining from the cultivated lands under this periods. Therefore if build up areas maintain this magnitude and rate, the implication is that the area will experience a great decrease of vegetation in the area. If vegetation cover continues to decrease at these rates found in this study, there will no more vegetation in the area in the near future that will result in change in weather elements or climate and will cause an increase in urban heat island or the area will experience excessive heat. The rate of wetland decrease is so high for example between 2000 and 2014, it was -7.63 , if the trend continues the area might face or experience a challenge of shortage of water due to reduction in hydrological systems. Therefore to achieve the SDG's for future development and generations; elements of the environment like vegetation and wetland should be controlled and help safeguard natural ecosystem sustainability.

\section{Conclusions and Recommendations}

This study was set to dictate the changes in urban land use and land cover change for Lafia area of Nasarawa State over a time period of 28 years (1986-2014), the areas of each land use were determined and the percentage rate of changes was examined. The monitoring of rapid urban growth is necessary in this modern world that we live in. It helps us to monitor the changes that have occurred in our natural environment thereby making necessary adjustment to the changes to prevent further damage to the environment. Population increase is causing more harm than good to the environment due to its activities; such as clearing up mostly vegetation cover and open spaces available in order to have more space for settlements. The method adopted in this study clearly demonstrated the potential of GIS and remote sensing techniques in measuring change pattern of urban land use. The determination of information on land use and land cover changes is essential for rural and urban development policies on land. Understanding the spatial dynamics of given land use and land cover is a foreknowledge for coordinating environmental resource planning and management.

From the foregoing, continuous detection of land use and land cover is necessary for effective and meaningful decision making. GIS and remote sensing have proved to be essential and reliable means of obtaining data on land use and land cover changes in an area. The detection of land use and land cover for effective and meaningful planning is often a problem; as a result of these, planners, researchers, and managers working at the landscape level have to rely on GIS and 
remote sensing technology for information gathering and manipulation. Moreover, monitoring of land use and land cover is necessary for effective and meaningful decision making. GIS and remote sensing have also proved to be essential and reliable means of obtaining data on land use and land cover changes in an area. The results from the findings will assist in providing information for city planners and decision makers to support sustainable urban development initiative. Therefore the use of land sat TM and ETM is recommended for the study of land use and land cover changes because of its low resolution and spatial coverage which enables a wide range of land to be covered. Hence Satellite Imageries should be taken consistently with defined time interval to aid a closer and up to date monitory of changes in the environment.

\section{Conflicts of Interest}

The authors declare no conflicts of interest regarding the publication of this paper.

\section{References}

[1] Giri, R. (2001) Assessments and Monitoring of Land Use and Land Cover GIS; a Mythological Study for North East Thailand.

[2] Martin (2007) Change Detection Accuracy Assessment Using SPOT Multispectral Imagery of the Rural-Urban Fringe. Remote Sensing of Environment, 30, 55-56. https://doi.org/10.1016/0034-4257(89)90047-3

[3] Ellis, E.(2011) Land Use and Land Cover Change. In: Cleveland, C.J., Ed., The Encyclopedia of Earth, Environmental information Coalition for Science and the Enviroment. http://www.eoearth.org/article/land -use and land-cover

[4] Medley, K.B., Okey, G., Barrett, M., Lucas, W.R. and Renwick, W.H. (1995) Landscape Change with Agricultural Intensification in a Rural Watershed, Southwestern Ohio, U.S.A. Landscape Ecology, 10, 161-176. https://doi.org/10.1007/BF00133029

[5] Meyer, W.B. (1992) Past and Present Land-Use and Land-Cover in the USA. Consequences, 1, 24-33.

[6] Verburg, P.H., Van Eck, J.R.R. and De Nijis, T.C.M. (2012) Projecting Land Use Transitions in the Gin Catchment, Tsri Lanka. University of Massachusetts, Amherst.

[7] Ademiluyi, I.A., Okude, A.S. and Akanni, C.O. (2008) An Appraisal of Land Use Land Cover Mapping in Nigeria. African Journal of Agric Research, 3, 582-586.

[8] Li, G., Moran, E. and Hetrick, S. (2013) Spatiotemporal Analysis of Land-Use Land-Cover Change in the Brazilian Amazon. International Journal of Remote Sensing, 34, 5953-5978.

[9] Akwa, L.V., Binbol, N.L., Samaila, I.K. and Marcus, D.M. (2007) Geographical Perspective on Nasarawa State. Onaivi Printing and Publishing Co. Ltd., Keffi.

[10] National Population Commission (2006) Nigeria's Population Census 2006.

[11] Anderson, J.R., Hardy, E.E., Roach, J.T. and Witmer, W.E. (1976) A Land-Use and Land-Cover Classification System for Use with Remote Sensing Data, U.S. Geological Survey Professional Paper 964, U.S. Geological Survey, Reston.

https://doi.org/10.3133/pp964

[12] Banki, T.C. (2009) Application of GIS in Dictating Land Use and Land Cover 
Changes in Akwanga and Its Environs. Nasarawa State. Unpublished B.Sc. Project, Geography Department, Nasarawa University, Keffi.

[13] Promise, J. (2012) Geospatial Analysis of Urban Land Use Change in Jos Metropolis. Dissertation, Department of Geography, University of Ibadan, Ibadan.

[14] Chukwunoson, E. (2012) Human Impact on the Landuse and Landcover Change of Yankari Game Reserve, Bauchi State. B.Sc. Unpublished Project, Department of Geography, University of Maiduguri, Maiduguri.

[15] NIMET (2015) Rainfall and Temperature Data Report of Lafia.

[16] Arulbalaji, P. and Gurugnanam, B. (2014) Geospatial Science for 16 Years of Variation in Land Use/Land Cover Practice Assessment around Salem District, South India. Journal of Geosciences and Geomatics, 2, 17-20. 